\title{
Aktivitas Antimikroba Fraksi Etil Asetat Daun Ceremai [Phyllanthus acidus (L.) Skeels] terhadap Bakteri Resisten Antimikroba dan Jamur dengan Metode KLT Bioautografi
}

\author{
Lanny Mulqie ${ }^{1, *}$, Kusnandar Anggadiredja² \\ 1Jl. Ranggagading No. 8 Bandung \\ 2Jl. Ganeca No. 10 Bandung \\ *Email korespondensi : lannymulqie.26@gmail.com
}

(Submit 15/03/2019, Revisi 05/09/2019, Diterima 20/12/2019)

\begin{abstract}
Abstrak
Resistensi dan toksisitas antimikroba menyebabkan penggunaan obat herbal sebagai alternatif pengobatan berbagai penyakit yang disebabkan oleh mikroba. Ekstrak etanol daun ceremai memiliki aktivitas terhadap VRE, MRCNS, dan Candida albicans. Penelitian ini bertujuan untuk mengetahui aktivitas antimikroba fraksi etil asetat daun ceremai terhadap bakteri resisten antimikroba [Methicillin-Resistant Staphylococcus aureus (MRSA), Methicillin-Resistant Coagulase Negative Staphylococcus (MRCNS), Vancomycin Resistant Enterococcus (VRE)] dan jamur uji (Candida albicans, Microsporum gypseum, dan Aspergillus niger) dengan metode KLT bioautografi. Fraksinasi dilakukan dengan cara ekstraksi cair-cair menggunakan pelarut dengan tingkat kepolaran yang berbeda, yaitu n-heksan, etil asetat, dan air. KLT bioautografi pada fraksi etil asetat daun ceremai dilakukan menggunakan fase diam silika gel $\mathrm{GF}_{254}$ dan pengembang etil asetat-asam format-asam asetat-air (100:10:10:22), menggunakan sitroborat sebagai penampak bercak. Pada hasil kromatogram terdapat 5 noda yang berfluoresensi hijau kekuningan dengan nilai rf noda 1 sebesar 0,35 ; noda 2 sebesar 0,43 , noda 3 sebesar 0,62 , noda 4 sebesar 0,75 dan noda 5 sebesar 0,90 setelah plat disemprot oleh sitroborat dan dilihat di bawah sinar UV. Hasil pengujian aktivitas antimikroba dengan metode KLT bioautografi menunjukkan terbentuknya zona bening yang dihasilkan noda pada plat yang ditempelkan pada media. Fraksi etil asetat daun ceremai memiliki aktivitas antimikroba terhadap bakteri resisten antimikroba (MRSA, MRCNS, dan VRE) dan jamur uji (Candida albicans, Microsporum gypseum, dan Aspergillus niger) yang dihasilkan oleh noda 1 ( $\mathrm{ff} 0,35$ ), noda 2 ( $\mathrm{rf} 0,43$ ), noda 3 ( rf 0,62 ), noda 4 ( $r f 0,75$ ), dan noda 5 (rf 0,90 ). Golongan senyawa yang diduga memiliki aktivitas antimikroba adalah flavonoid.
\end{abstract}

Kata kunci: Antimikroba, daun ceremai, fraksi etil asetat, KLT bioautografi

\section{Outline}

- Pendahuluan

- Metode

- Hasil dan Pembahasan

- Kesimpulan

- Daftar Pustaka 


\section{Pendahuluan}

Peningkatan resistensi dan toksisitas antimikroba menyebabkan penggunaan obat tradisional menjadi alternatif pengobatan berbagai penyakit yang disebabkan oleh mikroba. Pencarian obat-obatan yang berasal dari tanaman pun telah dipercepat dalam beberapa tahun terakhir ${ }^{1}$. Daun ceremai memiliki aktivitas analgetik, antipiretik, antirematik dan dapat menyembuhkan penyakit kuning, gatal-gatal, dan cacar air ${ }^{2}$. Fraksi etil asetat daun ceremai [Phyllanthus acidus (L.) Skeels] memiliki aktivitas antimikroba terhadap bakteri resisten antimikroba [Methicillin-Resistant Staphylococcus aureus (MRSA), Methicillin-Resistant Coagulase Negative Staphylococcus (MRCNS), Vancomycin Resistant Enterococcus (VRE)] dan jamur uji (Candida albicans, Microsporum gypseum, dan Aspergillus niger) sedangkan ekstrak etanol memiliki aktivitas antimikroba terhadap VRE, MRCNS, dan Candida albicans yang diuji menggunakan metode difusi agar ${ }^{3}$. Tujuan penelitian ini adalah untuk mengetahui aktivitas antimikroba fraksi etil asetat terhadap bakteri resisten antimikroba (MRSA, VRE, MRCNS) dan jamur uji (Candida albicans, Microsporum gypseum, dan Aspergillus niger) dengan menggunakan metode KLT bioautografi.

\section{Metode}

\section{A. Bahan}

Daun ceremai, etanol 96\%, Mueller Hinton Broth (MHB), Mueller Hinton Agar (MHA), Saboraud Dextrose Agar (SDA), $\mathrm{NaCl}$ fisiologis, aquades, asam asetat glasial, etil asetat, n-heksan, plat KLT, metanol, asam sitrat, asam borat.

\section{B. Metode}

1. Ekstraksi dan Fraksinasi

Ekstraksi simplisia sebanyak $700 \mathrm{~g}$ dilakukan dengan cara maserasi $3 \times 24$ jam menggunakan pelarut etanol $96 \%$. Ekstrak yang diperoleh kemudian diuapkan dengan rotary evaporator sampai diperoleh ekstrak kering ${ }^{4}$. Pengujian dilanjutkan dengan memfraksinasi ekstrak kering dengan metode ekstraksi cair-cair dengan tiga pelarut yang berbeda kepolarannya, yaitu n-heksan, etil asetat, dan n-butanol. Fraksi etil asetat diuapkan sampai diperoleh fraksi kental kemudian diuji aktivitas antimikroba terhadap bakteri resisten antimikroba dan jamur uji.

\section{Pengujian Aktivitas Antimikroba Fraksi Etil Asetat Daun Ceremai dengan Metode KLT Bioautografi}

Bioautografi dilakukan dengan cara menyentuhkan plat KLT pada permukaan media agar. Setelah inkubasi selama waktu tertentu maka letak zat aktif antimikroba ditandai dengan adanya zona hambat dengan latar belakang jernih. KLT dilakukan menggunakan fase diam silika gel $\mathrm{GF}_{254}$ dan pengembang etil asetat-asam formatasam asetat-air (100:10:10:22) yang menggunakan sitroborat sebagai penampak bercak $^{5}$. Hasil KLT ditempelkan ke media yang sudah mengandung mikroba uji, kemudian diinkubasi.

\section{Hasil dan Pembahasan}

\section{A. Hasil}

1. Hasil Ekstraksi dan Fraksinasi

Ekstraksi simplisia daun ceremai sebanyak $700 \mathrm{~g}$ dilakukan dengan cara maserasi 
menggunakan pelarut etanol 96\%. Ekstrak yang didapat kemudian diuapkan dengan rotary evaporator sehingga diperoleh ekstrak kering sebanyak $48,4 \mathrm{~g}$ dan rendemen yang diperoleh sebesar $7,03 \%$. Hasil fraksinasi $25 \mathrm{~g}$ ekstrak kering daun ceremai diperoleh fraksi etil asetat sebanyak $0,6 \mathrm{~g}$.

\section{Hasil Pengujian Aktivitas Antimikroba Fraksi Etil Asetat Daun Ceremai dengan Metode KLT Bioautografi}

Hasil KLT fraksi etil asetat daun ceremai menggunakan fase diam silika gel $\mathrm{GF}_{254}$ dan pengembang etil asetat-asam format-asam asetat-air (100:10:10:22) dengan penampak bercak sinar UV $\lambda 254 \mathrm{~nm}$ dan $\lambda 366 \mathrm{~nm}$, serta sitroborat diperoleh 5 noda. Nilai rf noda 1 sebesar 0,35 ; noda 2 sebesar 0,43 , noda 3 sebesar 0,62 , noda 4 sebesar 0,75 dan noda 5 sebesar 0,9 . Hasil pemantauan KLT fraksi etil asetat dapat dilihat pada Gambar 1.

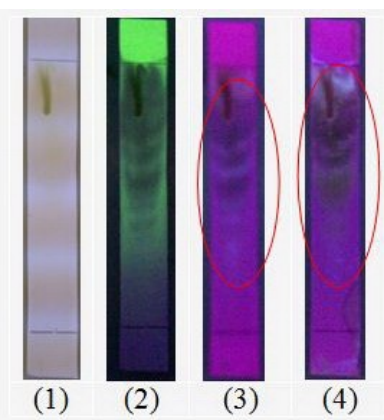

Gambar 1. Kromatogram lapis tipis pemantauan fraksi etil asetat, pelat silika gel $\mathrm{GF}_{254}$, pengembang etil asetat-asam format-asam asetat-air (100:10:10:22), (1) sinar tampak (2) di bawah sinar UV $\lambda 254 \mathrm{~nm}$, (3) di bawah sinar UV $\lambda 366$ $\mathrm{nm}$ (4) dengan penampak bercak sitroborat, di bawah sinar UV $\lambda 366 \mathrm{~nm}$.

KLT bioautografi fraksi etil asetat menggunakan pengembang etil asetat-asam formatasam asetat-air (100:10:10:22) menunjukkan terbentuknya zona hambat. Profil Kromatogram Plat KLT bioautografi fraksi etil asetat daun ceremai dapat dilihat pada Tabel 1 dan Hasil KLT bioautografi fraksi etil asetat menggunakan pengembang etil asetat-asam format-asam asetat-air (100:10:10:22) dapat dilihat pada Gambar 2.

\begin{tabular}{|c|c|c|c|c|c|c|}
\hline \multirow[t]{2}{*}{ Fraksi } & \multirow[t]{2}{*}{ Noda } & \multirow{2}{*}{$\begin{array}{l}\text { Nilai } \\
\text { Rf }\end{array}$} & \multicolumn{3}{|c|}{ Penampak Bercak } & \multirow{2}{*}{$\begin{array}{c}\text { Mikroba } \\
\text { yang } \\
\text { dihambat }\end{array}$} \\
\hline & & & UV $254 \mathrm{~nm}$ & UV $366 \mathrm{~nm}$ & Sitroborat & \\
\hline \multirow{5}{*}{$\begin{array}{c}\text { Etil } \\
\text { asetat }\end{array}$} & 1 & 0,35 & kuning & $\begin{array}{c}\text { kuning } \\
\text { kehijauan }\end{array}$ & $\begin{array}{c}\text { hijau } \\
\text { kekuningan }\end{array}$ & $\begin{array}{c}\text { (2), }(3),(4), \\
(5)\end{array}$ \\
\hline & 2 & 0,43 & kuning & $\begin{array}{c}\text { kuning } \\
\text { kehijauan }\end{array}$ & $\begin{array}{c}\text { hijau } \\
\text { kekuningan }\end{array}$ & $\begin{array}{c}\text { (2), (3), (4), } \\
\text { (5) }\end{array}$ \\
\hline & 3 & 0,62 & kuning & $\begin{array}{l}\text { kuning } \\
\text { kehijauan }\end{array}$ & $\begin{array}{c}\text { hijau } \\
\text { kekuningan }\end{array}$ & (2), (3) \\
\hline & 4 & 0,75 & kuning & $\begin{array}{c}\text { kuning } \\
\text { kehijauan }\end{array}$ & $\begin{array}{c}\text { hijau } \\
\text { kekuningan }\end{array}$ & (3), (6) \\
\hline & 5 & 0,90 & kuning & $\begin{array}{c}\text { kuning } \\
\text { kehijauan }\end{array}$ & $\begin{array}{c}\text { hijau } \\
\text { kekuningan }\end{array}$ & $(1),(3),(6)$ \\
\hline
\end{tabular}

Keterangan:(1)MRSA, (2) VRE, (3) MRCNS, (4) Aspergillus niger, (5) Candida albicans,

(6) Microsporum gypseum.

\section{B. Pembahasan}

Metode maserasi dipilih untuk mengantisipasi kerusakan senyawa yang bersifat termolabil. Etanol digunakan sebagai pelarut karena dapat menarik senyawa yang 


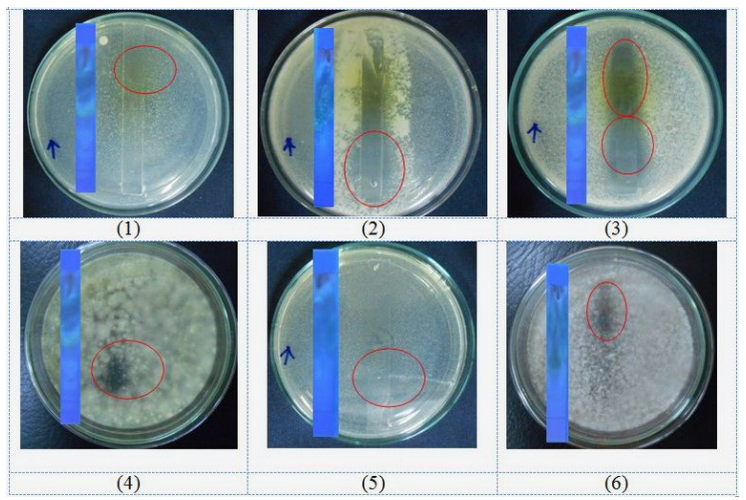

Gambar 2. Hasil KLT bioautografi, (1) MRSA, (2) VRE, (3) MRCNS, (4) Aspergillus niger, (5) Candida albicans, (6) Microsporum gypseum.

bersifat polar dan non polar. Fraksinasi dilakukan untuk memisahkan senyawa berdasarkan tingkat kepolarannya. Pemantauan KLT fraksi etil asetat daun ceremai menggunakan fase diam silika gel $\mathrm{GF}_{254}$ dan pengembang etil asetat-asam formatasam asetat-air (100:10:10:22) dengan penampak bercak sinar UV $\lambda 254 \mathrm{~nm}$ dan $\lambda 366$ $\mathrm{nm}$, serta sitroborat diperoleh 5 noda. Plat hasil elusi diuji aktivitasnya menggunakan metode KLT bioautografi. Hasil KLT bioautografi fraksi etil asetat menggunakan pengembang etil asetat-asam format-asam asetat-air (100:10:10:22) menunjukkan bahwa terbentuknya zona hambat yang memperlihatkan adanya aktivitas antimikroba terhadap pertumbuhan mikroba uji. Noda 1 (rf 0,35) dan noda 2 (rf 0,43) dapat menghambat pertumbuhan VRE, MRCNS, Aspergillus niger, dan Candida albicans. Noda 3 (rf 0,62) dapat menghambat pertumbuhan VRE dan MRCNS sedangkan noda 4 (rf 0,75 ) dapat menghambat pertumbuhan MRCNS dan Microsporum gypseum. Aktivitas antimikroba fraksi etil asetat ditunjukkan juga oleh noda 5 (rf 0,9$)$ yang dapat menghambat pertumbuhan MRSA, MRCNS dan Microsporum gypseum. Hasil kromatogram pada Gambar 1 menunjukkan bahwa plat yang menggunakan penampak bercak sitroborat menghasilkan noda yang berfluoresensi hijau kekuningan. Hal ini menunjukkan bahwa fraksi etil asetat mengandung flavonoid.

\section{Kesimpulan}

Fraksi etil asetat daun ceremai memiliki aktivitas antimikroba terhadap bakteri resisten antimikroba (MRSA, MRCNS, dan VRE) dan jamur uji (Candida albicans, Microsporum gypseum, dan Aspergillus niger) yang dihasilkan oleh noda 1 (rf 0,35 ), noda 2 (If 0,43 ), noda 3 (rf 0,62 ), noda 4 ( $r f 0,75$ ), dan noda 5 ( $r$ 0,90 ). Golongan senyawa yang diduga memiliki aktivitas antimikroba adalah flavonoid.

\section{Daftar Pustaka}

1. Cowan, M. M. Plant Products as Antimicrobial Agents. Clinical Microbiolgy Reviews. 1999; 12(4):564-582.

2. Jain, N.K., Singhai, A.K. Protective effects of Phyllanthus acidus (L.) Skeels leaf extracts on acetaminophen and thioacetamide induced hepatic injuries in Wistar rats. Asian Pacific Journal of Tropical Medicine. 2011; 470-474.

3. Mulqie, L., Anggadiredja, K. Antimicrobial Activity of Fractions of Ceremai (Phyllanthus acidus (L.) Skeels) Leaves Extract Against Antimicrobial Resistant Bacteria and Fungi. In: Proceeding of the International Conference on Herbal 
Medicine Industrialization as Complementary Therapy in Natural Disasters. 2015 Jan 7; Yogyakarta, Indonesia: 2015. p. 22-28.

4. Depkes RI. Parameter Umum Standar Ekstrak Tumbuhan Obat. Jakarta: Direktorat jendral Pengawasan Obat dan Makanan; 2000.

5. Anggietha, M. Isolasi Flavonoid dari Ekstrak Metanol Daun Ceremai (Phyllanthus acidus (L.) Skeels). Skripsi Sarjana Farmasi Institut Teknologi Bandung; 2011. 